\title{
The Combination of Fighting Against the Crime of Trafficking in People of Police Forces during the Period of International Integration
}

\author{
Major, Dr. Nguyen Thi Thuy Hanh \\ Police Academy - Vietnam
}

\begin{abstract}
Summary: The combination of fighting against human trafficking is a matter of principle and governed by the State's legal documents, the Directive and the Resolution of the Public Security sector. In fact, good implementation of coordination between police forces in the fight against crimes of trafficking in people has the effect of promoting cooperative forces, supporting each other to find common solutions. for the struggle, set up a legal basis to conduct activities to exchange information on crimes, support material facilities, human resources and technical progress for timely application of measures professional operations to detect and prevent crimes of human trafficking in the current international integration period.
\end{abstract}

Keywords: Coordination, police force, human trafficking

DOI: $10.7176 / \mathrm{JLPG} / 85-03$

Publication date:May $31^{\text {st }} 2019$

Coordinating in the prevention and combat of crimes of trafficking in people also helps to build a cooperative relationship between domestic and foreign forces to support comprehensive cooperation in many areas of social life, This is the basis for the effective application of measures to fight against criminals in an international way. Moreover, doing well the coordination in crime prevention and control also contributes to building a broad security frontier in many countries, creating conditions to promptly prevent and effectively handle the situation. Crime of international activities in general, crimes of human trafficking in particular are taking place increasingly fierce, contributing to ensuring security and stability in each country, region and the world.

\section{Role of police force and trafficking in people in the context of economic integration}

\subsection{Role of police force}

In the Vietnam People's Police, the People's Police have a very important position and role. The glorious heroic history of the Vietnamese revolution from the General Revolt in August 1945, gave birth to the Democratic Republic of Vietnam, to the victory of the resistance against French colonialism (1945 - 1954); resistance against American imperialism (1954-1975); overcoming the consequences of war, preventing and fighting against smashes and anti-destructive activities in the enemy's post-war plan and international reactionary; protect the territorial integrity of the Fatherland in the border wars of the Southwest and the North; Particularly important results have been achieved after more than 30 years of renovation, opening and international integration, enhancing the synergy of building and protecting the Fatherland, prestige and image of the country in the international arena. all recognized the deep imprints, victories, great contributions of the people's police force, including the people's police.

Today, meeting the requirements of Industry 4.0 Revolution takes place worldwide, there is the potential to improve global income levels and improve the quality of life for people worldwide, access to technology number; Technology has created new products and services that can increase efficiency and fun in life. In this context, the police force continued to create new victories, especially outstanding in the fight against crimes of transnational human trafficking with sophisticated tricks, with more modern technology. Accompanied by these achievements and victories, there were many brave officers and soldiers who sacrificed, suffered injuries, lost a part of their blood.

\subsection{Crime of trafficking in people}

Crime of trafficking in people is a dangerous act for the society as stipulated in the Criminal Code, because a person with criminal responsibility can perform it by using force, threatening to use force, deception or defense. another paragraph to: Transfer or receive people to hand over or receive money, property or other material benefits; Transfer or receive people for sexual exploitation, forced labor, taking the victim's body parts or for other inhuman purposes; Recruiting, transporting and harboring other persons to commit acts of transferring or receiving people to hand over or receive money, properties or other material benefits; Transfer or receive people for sexual exploitation, forced labor, taking the victim's body parts or for other inhuman purposes.

Characteristics of human trafficking crimes are transnational and international activities related to economic, social, security, defense and foreign affairs. Crime of trafficking in human beings is classified as crimes against humanity because it seriously violates human rights, in which there are the most basic rights such as the right to 
freedom of movement, the right to safety and security. network, health, labor rights ... The consequences of trafficking for victims and victims' families in particular, for society in general, are very heavy. Victims must suffer physiological damage, harm to their health and even their lives, destabilizing the social security order.

\section{Current status of human trafficking in Vietnam}

As well as drug crimes, trafficking crimes bring high profits to criminals. It is because of this specificity that human trafficking lines extend across countries and territories around the world. Countries with large numbers of victims are Thailand, China, Nigeria, Albania, Bulgaria, Belarus, Moldova and Ukaina. If before, buying and selling people was recorded mainly because of the purpose of sexual exploitation, now, buying and selling people for the purpose of exploiting labor is tending to increase. Many people have fallen into forced labor, forced to work in factories, factories, farms, construction sites, mines, on fishing boats or in residential areas in the form of help. family work. Victims are often abused both physically and mentally, without health care and access to social services. Many of them are forced to work 15 - 20 hours a day, have no recurring holidays, have little or no respite, have their personal papers confiscated, and are not allowed to leave the workplace. or contact anyone outside the scope of work, discrimination, violence and gender prejudice. Male victims were taken to fishing boats, imprisoned as prisoners, floating on the beach for months or years, using heavy and dangerous equipment. The threat of physical abuse and abuse is frequent; those who try to resist or fall ill can be killed or thrown into the sea ...

In Vietnam, according to the report of the Criminal Police Department (C45) from 2012 to the first 6 months of 2017, the whole country has detected 2,244 trafficking cases with 3,369 subjects, and 5,024 victims were sold. In general, the crime situation of trafficking in people evolves more and more complicated, sophisticated nature and tricks, and is often organized and hooked with foreigners. It is noteworthy that during this period, men were bought and sold (in Lao Cai, Quang Ninh, Hai Duong); buying and selling organs (in Can Tho, Soc Trang, Bac Lieu, Vinh Long, Ninh Thuan); appropriating kidnapping children (in Lai Chau, Ha Giang) and buying and selling babies, selling children in the fetus (in Hanoi, Quang Ninh, Soc Trang)

Table 2.1. The situation of trafficking crimes nationwide

\begin{tabular}{|c|c|c|c|}
\hline Year & Number of cases & Number of objects & Number of victims \\
\hline $\mathbf{2 0 0 6}$ & 328 & 607 & 966 \\
\hline $\mathbf{2 0 0 7}$ & 369 & 681 & 938 \\
\hline $\mathbf{2 0 0 8}$ & 375 & 718 & 981 \\
\hline $\mathbf{2 0 0 9}$ & 395 & 748 & 869 \\
\hline $\mathbf{2 0 1 0}$ & 429 & 683 & 671 \\
\hline $\mathbf{2 0 1 1}$ & 454 & 670 & 821 \\
\hline $\mathbf{2 0 1 2}$ & 478 & 809 & 883 \\
\hline $\mathbf{2 0 1 3}$ & 507 & 697 & 982 \\
\hline $\mathbf{2 0 1 4}$ & 469 & 685 & 1.031 \\
\hline $\mathbf{2 0 1 5}$ & 407 & 655 & 1.000 \\
\hline Total & $\mathbf{4 . 2 1 1}$ & $\mathbf{6 . 9 5 3}$ & $\mathbf{9 . 1 4 2}$ \\
\hline
\end{tabular}

Source: Annual report of C45 and PC45 and dossiers of cases of purchase and sale of people stored at Department of C53; Division of PC53 of Northern provinces and cities.

Through the survey and assessment results, it shows that the reason for the crime of trafficking in people in our country continues to be complicated due to some basic causes:

Firstly, the market economy and the integration trend have brought about great achievements, but its downside along with the global economic recession, the socio-economic situation in the country and human life. People still face many difficulties, the process of urbanization is accelerated, the population is large, the number of unemployed and unemployed leads to income disparities, the above-mentioned factors affect the rise of said criminals. In general, criminals buy and sell people in particular.

Secondly, the propaganda, education, dissemination and law enforcement among the people are still limited, not extensive, most of the victims do not have information when looking for work or marrying foreign husbands so they are easily deceived. trick, no skills to protect themselves. According to the report on the review of the situation of human trafficking crime to China on June 1, 2017 of C45, the number of Vietnamese women married to Chinese husbands did not conduct marriage registration according to regulations of 16,428 people; The number of women and children absent in the locality, suspected of being sold, is 1,474 people.

Thirdly, the management of entry, exit and state management in border areas, especially roads, has loopholes, shortcomings, thin forces can not control the unqualified lines, the way of erosion. In the border areas, the offenders are taking advantage of bringing people, especially women and children across the border, to organizing other people to illegally exit ... Working on the situation of functional forces About crimes of trafficking in people, there are many limitations, basic operations have not ensured depth and have not been effective.

Fourthly, the issuance of documents guiding the application of the law is not timely. Although the Law on 
Human Trafficking Prevention and Control came into effect on January 1, 2012, the Prime Minister issued a Decision approving the action program on prevention and trafficking in human trafficking in the period of 20162020. Joint Circular No. 01 provides guidance for criminal prosecution of persons who have committed acts of trafficking in people, buying and selling, fraudulently exchanging or appropriating children. However, because the new Code 2015 has not yet taken effect, many cases of human trafficking are in practice due to the unanimous evidence of the prosecution agencies' evidence, thus affecting the investigation and trial process. Crime of trafficking in people, even not prosecuting the case or not prosecuting the accused.

Fifth, there has not been a specialized force to prevent and combat human trafficking crimes. Police are the core force to prevent and combat human trafficking crimes, but until now, most localities and units have not established specialized forces to prevent and combat human trafficking crimes. At the police departments at the provincial level, mainly cages, coupled with professional teams to implement prevention and investigation activities when a case of trafficking takes place should result in limited competition. (In the Ministry of Public Security, there is only one room in the C45 Department, the local police only have one locality to establish a Human Trafficking Prevention and Control Team under PC45 (Hanoi).

Sixthly, international cooperation in combating crime against trafficking in people despite being concerned but not as effective as expected due to many reasons such as judicial procedures, diplomatic barriers and systems law. Many requests from the Vietnamese side suggest that the relevant authorities of your country verify (especially cases of victim rescue), but for a long time still did not receive a response note, resulting in rescue. arresting and arresting subjects who escape to foreign countries with low efficiency. Some cases need to appoint a working group to go abroad to investigate to rescue victims or exploit objects of Vietnamese people arrested by the police of your country for trafficking in people to collect materials, evidence and arrest of suspects who are operating in the country but encounter many difficulties due to time-consuming foreign and immigration procedures.

\section{Relationships between criminal police forces and police forces inside and outside the sector in preventing human trafficking crimes}

\subsection{Coordinate with the police forces}

- Coordinate with police force to administer administrative and social order and safety

The criminal police force cooperates with the police force to manage administrative and social safety and strictly manages service establishments (such as discos, hotels, motels and restaurants). , inns ...), tourism services, labor export, especially marriage brokerage services, strictly control the licensing of these services, and also need to check closely. procedures in service activities to ensure these activities in accordance with the law.

Through the management of civil status, household registration, temporary residence registration, temporary absence, entry and exit to detect objects in the area, objects from other geographical areas or local objects. I have behaviors, signs of suspicion of human trafficking. Strictly manage the activities of foreigners in the Vietnamese territory, especially those related to tourism activities, marriage brokerage, job introduction and recruitment of workers to work in the country. In addition, those who commit acts of violating Vietnamese laws.

Coordinate with the police force to administer social order and safety in the review and detection of conditional objects, manifest doubts about criminal activities to be included in the collection and coordination areas. in review and approval; coordinate in propagating and mobilizing people to raise their sense of law observance and detect crimes; coordinating in the management and education of people who have a wrong past so that they do not commit crimes of human trafficking, helping them to re-integrate into the community. Besides, criminal police also coordinate in preventing human trafficking offenses, rescue victims.

- Coordinate with traffic police force, police order, mobile police

Coordinate with traffic police force, order police, mobile police in patrolling to timely detect human transport and trafficking lines; coordinate in checking and maintaining order in complicated areas, areas and routes related to activities of human trafficking crimes. Besides, through grasping the situation on the characteristics of the area, the rules of operation and the method of tricks of the crimes of human trafficking, the criminal police force in coordination with the traffic police force, Order Police, Mobile Police regularly conduct activities to check the pier, bus station, public areas, routes, key areas to timely detect the offenders, criminal acts such as transporting, transferring victims to other areas or bringing victims abroad.

- Coordinate with police forces to investigate drug-related crimes

Criminal police force in cooperation with police forces investigating crimes on drug procurement in order to detect the relationship between people trafficking in people with drug-related subjects, determine the relationship system, rules of activity of collusion among objects of activities of committing trafficking in human beings with objects transporting narcotics; On that basis, appropriate preventive and preventive measures shall be applied according to the functions of each force.

- Coordinate with the Immigration Management force under the Ministry of Public Security

The criminal police force coordinates regularly with the Immigration Department (A72) and the Immigration 
Department (PA72) of local police to exchange and verify the immigration information of the police. suspect suspicion of human trafficking. Timely detection of suspected cases related to trafficking of people across borders. - Coordinate with Interpol and Aseanapol offices in Vietnam

In the prevention of human trafficking crimes, criminal police forces often coordinate with Interpol Office, Aseanapol to exchange information, establish hotlines to share information on subjects of crime of human trafficking. across the border, conducting mutual legal assistance activities, rescuing and receiving victims of trafficking and returning criminals.

- Coordinate with the Police for Criminal Judgment Execution and judicial support, the force to manage Professional Records

Criminal police force in coordination with police forces enforce criminal convictions and judicial support to gather information on the process of detention and renovation of subjects in prisons, educational institutions, schools educate when these subjects return to society (discovering information reflecting on those who are active in the crime of trafficking but have not been arrested yet, informing the police force to take measures. continue to arrest, detect the relationships of the objects in the prison with those who are still out of society, help the police force to timely identify the objects to take measures to monitor and manage appropriate, on the basis of grasping the ideological developments, the observance of rules and regulations In the detention center, after the object was released to the locality, the Criminal Execution Police and judicial support provided information and documents to the criminal police force to put the object into the investigation area, classification and management measures to serve the prevention of human trafficking crimes.

In order to prevent trafficking crimes, the criminal police force also coordinates with the management force of professional records in searching documents and information about the object (history, relationship, criminal record, the ...), exploitation of records, the system of archives, construction and establishment of professional records to serve the requirements of identifying criminals, monitoring and supervision to prevent the object of implementing crime human trafficking.

- Coordinate with professional technical forces and police forces to prevent criminals from using high technology in preventing human trafficking crimes. In the current period, the users often take advantage of or use devices such as mobile phones, fixed phones, intercity phones, international phones, satellite phones, Internet ... to contact and discuss, exchange information to plan the implementation of crime. Therefore, the criminal police forces actively coordinate with professional technical forces, police forces to prevent crime use high technology to check and supervise the activities of the object to collect information information, documents about the plan, criminal activity of the object as well as detecting suspicious calls, locating exactly where the criminals are hiding. Thereby, it can ensure the initiative in timely detecting the exact and effective force when preventing the criminal act of the object.

\subsection{Coordinate with forces outside the Public Security sector}

- Coordinate with border guards in preventing trafficking. The criminal police forces coordinate with the border guard force to bring into full play the effectiveness of control measures at border and border gates, prevent the illegal illegally crossing the border; coordinate in rescuing and receiving victims; coordinate in implementing the propaganda and mobilization of the people in the border areas to be vigilant and timely discover and provide information for the prevention of human trafficking as well as the handling of criminal acts; coordinate support for forces, means, and information exchange in the prevention process; coordinating in transferring information, documents and records on the ongoing case related to human trafficking crimes; coordinating with and coordinating programs of cooperation with countries sharing borders to implement preventive activities.

- Coordinate with the culture and information industry, press agencies and media to propagate the State's guidelines and policies on the prevention and control of human trafficking crimes and disseminate methods of manipulating criminal activities, and key areas and routes for human trafficking for victims, families, at-risk subjects, union members and youths to raise vigilance to prevent and denounce crimes of human trafficking.

- Coordinate with central justice agencies to issue legal documents to guide the proper and uniform application of the law in the process of settling the case. Along with urgently studying and issuing guidelines on uniform application of law, the Supreme People's Court is always interested in researching and answering professional issues or obstacles in practical application. using the law, helping the courts at all levels to apply the law to improve the quality of the trial of human trafficking cases. Organize seminars, survey the implementation of the law on investigation and prosecution of human trafficking crimes, make specific recommendations and proposals to perfect the legal system on crime prevention and control human trafficking.

- Coordinate with the diplomatic agencies to grasp the situation, promptly carry out the protection work for Vietnamese citizens who are victims of trafficking abroad, and coordinate with competent agencies of Vietnam and foreign countries carry out verification and do other necessary procedures to bring victims to Vietnamese citizens back home.

- Coordinate with the Labor, Invalids and Social Affairs to conduct surveys and statistics on returned victims of trafficking from abroad, investigating organizations to understand the circumstances of each victim as a basis 
for construction. set up and organize the implementation of plans to support victims to stabilize their lives; mobilize the participation of agencies, organizations and individuals in supporting victims of reintegration into the community, avoiding stigma and discrimination; strengthening measures to support prevention according to the functions and tasks of the industry through programs of hunger elimination, poverty reduction, vocational training, job creation, programs to prevent prostitution, prevention of young sexual abuse I, vocational training program for workers in rural, remote and remote areas ...

- Coordinate with the Central Committee of the Vietnam Women's Union: Propaganda, education and counseling in the community on human trafficking prevention, support and support for trafficked victims to reintegrate and add up. VND, preventing the situation of victims especially women who are trafficked and sexually abused for commercial purposes. On the other hand, coordinate with the Women's Union to develop a plan to educate and raise awareness among people in the community on the prevention and combat of human trafficking crimes; integrating human trafficking prevention and control programs with building a network of propagandists to villages to organize clubs, organizing training courses to improve the capacity of propagandists and officials of declaration skills prevention and fight against MBN. Media organizations focus on high-risk groups, aged 15-30. Communication is associated with programs to support capital, create jobs and reduce poverty, thereby limiting the causes of human trafficking.

- Coordinate with People's Procuracy and People's Court: Criminal police force in coordination with People's Procuracy and People's Court in promptly resolving and severely adjudicating trafficking cases people, especially coordinating to organize mobile trial cases to deter criminals and launch mass movements; coordinate in strengthening the guidance, direction and quality control to implement the right to prosecution and to supervise and inspect the trial, initially studying to build a database of management of human trafficking projects.

\subsection{International cooperation in preventing human trafficking crimes}

The purpose of international cooperation in preventing criminal trafficking of criminal police is to exchange information related to the object, victims of human trafficking, exchange of struggle experiences, difficulties of the parties when struggling with this type of crime, create conditions for each party to fulfill the requirements and tasks that are committed in preventing crime of human trafficking.

The content of international cooperation in preventing human trafficking crimes:

Exchange and share information about human trafficking crimes such as objects, operation tactics, victims ...;

Exchange information on the situation of fighting against human trafficking crimes of each country;

Implement drafting, negotiating and signing documents related to the struggle against human trafficking;

Cooperation in training, scientific research, document exchange to improve the qualifications of staff in law enforcement and judicial agencies to implement the task of preventing human trafficking crimes;

Cooperation in exchanging and transferring technologies and technical facilities for prevention of human trafficking crimes;

\section{Solutions to improve the coordination and prevention of human trafficking crime of police forces during the international integration period}

In order to contribute to improving the effectiveness of prevention and fighting against human trafficking crimes in the coming time, it is necessary to synchronize some solutions when implementing the following basic coordination:

Firstly, completing the legal system as a legal basis for the relationship between the criminal police and other forces. In fact, in the fight against crime of trafficking, we only rely on the documents of the Government and joint circulars and decrees ... prescribing a number of contents such as: bases for determining victims being trafficked, prescribing a number of articles of the law on prevention and combat of human trafficking and victim assistance ... without any written regulations on coordination in combating the prevention and combat of human trafficking crimes. Therefore, it is necessary to issue specific regulations on the coordination relationship between the Ministry of Public Security and other ministries, as well as the coordination relationship between the criminal police force and other forces in the fight against, Against crime of trafficking in people.

Secondly, continue to innovate the forms of cooperative relations in preventing and combating crimes of human trafficking. In the struggle to prevent and combat this type of crime, it is necessary to regularly and continuously coordinate, to regularly check and supervise the results and organize the withdrawal of experiences in time to adjust and supplement the suitable for the practical situation. On the other hand, in a coordinated relationship, it is necessary to anticipate unexpected situations and solutions between the parties to avoid overlapping and untimely handling so that crimes occur or endanger the victim.

Thirdly, ensuring the effectiveness of coordination between the City Urban Police force with other forces in receiving, rescuing and protecting victims of trafficking. The trafficking victims return to provinces and cities directly under the Central Government that have not yet carried out this work; at the same time, organize the implementation of the victim support plan based on the survey results and statistics on cases of returning victims 
from foreign countries. Coordinating and promoting relevant agencies in verifying victims, assisting victims in household registration, granting people's identity cards. Presiding and supporting job creation for victims through the system of vocational training centers and job introduction in the locality.

Fourthly, build a coordination mechanism to exchange information and improve the process of receiving and processing information on human trafficking crimes between criminal police forces and other forces. The process of organizing and coordinating the information of the parties is still formative, not following the unified process, so the information is not timely and time-consuming, leading to poor efficiency in the fight against human trafficking. . Therefore, in the coming time, it is necessary to develop a mechanism to exchange information and improve the process of receiving and processing information on human trafficking crimes as well as work processes related to coordination relations in the direction. specifying cooperation documents signed between the parties; clearly define the responsibilities of each force in receiving and processing all kinds of information such as information on methods, tricks, objects, information on each country's legal provisions in preventing and fight against crimes of human trafficking; information about victims.

Fifth, strengthen international cooperation on the prevention and control of human trafficking crimes, effectively implement multilateral and bilateral international treaties on the prevention and combat of human trafficking crimes, such as the Protocol on the prevention, repression and punishment of human trafficking, especially women and children, in addition to the United Nations Convention on Fighting Transnational Organized Crime; Optional protocol on the sale of children, prostitution and child pornography, in addition to the Convention on the Rights of the Child. Besides, it is necessary to strengthen the implementation of bilateral agreements with neighboring countries, such as the Agreement between the Government of the Socialist Republic of Vietnam and the Kingdom of Thailand on bilateral cooperation to eliminate human trafficking, especially women and children and helping trafficked victims; Agreement between the Government of the Socialist Republic of Vietnam and the Government of the People's Republic of China on strengthening cooperation in prevention and control of human trafficking; Agreement between the Government of the Socialist Republic of Vietnam and the Government of the Lao People's Democratic Republic on cooperation in preventing and combating trafficking and protecting trafficked victims; The agreement between the Government of the Socialist Republic of Vietnam and the Royal Government of Cambodia on bilateral cooperation to eliminate trafficking in women and children and help trafficked victims; The agreement between the Government of the Socialist Republic of Vietnam and the Royal Government of Cambodia on the standard process in identifying and repatriating trafficked victims returned.

Along with the increase of crime in general, crime of trafficking is also increasing with the nature and level of danger increasing, the consequences are getting bigger and bigger, the tricks are becoming more sophisticated and there are many cases of carrying organization, transnational. In Vietnam, trafficking crimes, especially the sale of women to foreign countries (mostly sold to China) with the main purpose of sexual exploitation, exploitation of labor, being used for commercial purposes or other inhuman purposes, going on is complicated and difficult to control. The consequence of human trafficking crimes is to adversely affect morality, lifestyle, fine traditions, social order and rob the happiness of many families, causing much suffering and humiliation for themselves. victims and their families, affecting national security. To proactively prevent this type of crime, to minimize the consequences of this type of crime, the criminal police force has used many measures to curb the rise of crime, prevent timely blocking human trafficking acts, peace and happiness in the night.

\section{References}

1. Steering Committee of 130 / CP (2010), Evaluation Report of International Organizations in Vietnam at the Conference on summarizing 5 years of implementing the action program on prevention of trafficking in women and children, Hanoi.

2. Steering Committee 138 / CP (2011-2015), 5-year review report on implementation of the action program on prevention and control of human trafficking crime in the period 2011 - 2015, Hanoi.

3. Ministry of Public Security (2013), Directive No. 02 / CT-BCA-C41 dated April 1, 2013 of the Minister of Public Security on focusing on reorganizing and improving the quality and efficiency of the professional affairs Edition of the communist forces in the new situation.

4. Ministry of Public Security (2013), Plan No. 374 / C45 dated March 22, 2013 on improving the effectiveness of the struggle against human trafficking in 2013, Hanoi.

5. Ministry of Justice (2010), International and national legal manual on prevention and control of human trafficking, Justice Publishing House, Hanoi.

6. Government (2015), Decision No. 2546 / QD-TTg dated December 31, 2015 approving the Action Program on prevention and control of human trafficking crimes in the period of 2016 - 2020, Hanoi

7. Government (2013), Joint Circular No. 35/2013 / TT - BLĐTBXH dated December 30, 2013, guiding the implementation of a number of articles of Decree No. 09/2013 / ND - CP dated January 11, 2013 of detailed regulations on implementation of a number of articles of the Law on prevention and control of human trafficking 
8. Nguyen Cong Tam (2015), Preventing crimes of trafficking in provinces and cities in the South ", doctoral thesis, PPA - 2015

9. Phan Cong Chuyen (2015), "Investigation of crimes of trafficking in people across Vietnam - Cambodia according to the function of the Criminal Police force", Doctoral Dissertation - People's Police Academy

10. ChenDa - Keo (2011), Crime human trafficking in Cambodia. From assumptions to evidence, PhD Thesis 